\title{
YEAST CONCENTRATION IN THE DIET DEFINES DROSOPHILA METABOLISM OF BOTH PARENTAL AND OFFSPRING GENERATIONS
}

\author{
O. M. STRILBYTSKA ${ }^{1 \bowtie}$, N. P. STEFANYSHYN ${ }^{1}$, \\ U. V. SEMANIUK ${ }^{1}$, O. V. LUSHCHAK ${ }^{1,2 \otimes}$ \\ ${ }^{1}$ Department of Biochemistry and Biotechnology, Vasyl Stefanyk Precarpathian \\ National University, Ivano-Frankivsk, Ukraine; \\ ${ }^{2}$ Research and Development University, Ivano-Frankivsk, Ukraine; \\ 凹e-mail: olya_b08@ukr.net or oleh.lushchak@pnu.edu.ua
}

Received: 18 April 2021; Accepted: 12 November 2021

Parental dietary nutrients epigenetically influence offspring metabolism. Our analysis revealed unforeseen patterns in how enzymes of the main metabolic pathways respond to protein content in the diet. We reared parental flies Drosophila melanogaster on four types of diet with different dry yeast concentrations ranging from $0.25 \%$ to $15 \%$. The subsequent generation was fed by the same diet, so the only variable in the experiments was the yeast concentration in the parental diet. We showed that protein restriction in the parental diet led to higher lactate dehydrogenase (LDH) activity in parents, and this effect was inherited in their progeny. The transgenerational effect of parental dietary yeast on malate dehydrogenase (MDH) activity was found only in males. An elevated level of dietary yeast was sufficient to enhance alanine transaminase (ALT) and aspartate transaminase (AST) activity in parents, however, did not affect ALT activity and decreased AST in their offspring. A low yeast parental diet was shown to cause higher urea content in F1 males. It is concluded that parental dietary yeast plays a critical role in metabolic health that can be inherited through generation.

Keywords: nutrition, diet, protein, yeast, parents, offspring, metabolism, fruit fly.

$\mathrm{N}$

utrition is one of the main factors influencing the lifespan, reproduction, metabolism, and survival of living organisms [1-3]. Considerable interest devoted to the effects of a single macronutrient such as proteins and carbohydrates on phenotypic traits of the organism [4]. Drosophila melanogaster has been successfully used as a model organism to study the effects of diet or certain substances on organismal health. A high degree of similarity of energy homeostasis, metabolic and signaling pathways of transduction in Drosophila and mammals, makes fruit fly an accessible model object to study the mechanisms underlying metabolic and transgenerational effects [5]. Our previous study showed that parental dietary protein-to-carbohydrate ratio $(\mathrm{P}: \mathrm{C})$ influences lifespan, physiological traits, and metabolism of not only parental flies but in their offspring [6]. Moreover, we demonstrated life span and metabolism, are affected by dietary sucrose content [3]. We also previously studied that variable dietary protein content in the diet of parental generation affects antioxidant capacity in adult offspring Drosophila.

Nutrition and various dietary components can affect the change in gene expression pattern, without changing the DNA sequence, and may be inherited through generations [7]. Lack of nutrients in several critical stages of development, both in utero and in childhood, is associated with the development of metabolic and cardiovascular diseases in adulthood. Thus, calorie restriction and a low-protein diet during fetal development in rodents can affect the metabolic status of offspring [8]. This is because proteins are not only important structural materials

(C) 2021 Strilbytska O.M. et al. This is an open-access article distributed under the terms of the Creative Commons Attribution License, which permits unrestricted use, distribution, and reproduction in any medium, provided the original author and source are credited. 
for the body but are also involved in enzymatic reactions and are responsible for the transmission of cellular signals [9].

Dietary components mediate effects on physiological and metabolic traits via intracellular signaling pathways. Regulatory pathways, such as insulin/IGF and target rapamycin signaling pathway (TOR) signaling, are highly conserved and provide significant control over metabolism, including lipid and glucose homeostasis. TOR may be activated by single amino acid $[10,11]$. It can provide a causal explanation of recent data evidencing that reduction in the proportion of protein in the diet, rather than DR per se, could promote longevity in various animal models $[12,13]$. TOR signaling pathway responds not only to the nutrient concentration but also to the nutrient proportion [14]. In contrast to previous studies in Drosophila, recent results conclude that both carbohydrates and protein have measurable effects. For example, in Drosophila, the effect of yeast in the diet on lifespan depends on target TOR [15].

We have previously shown, that physiological traits and metabolism were affected by the dietary protein-to-carbohydrate ratio $(\mathrm{P}: \mathrm{C})$ of the prior adult generation [6]. However, the molecular mechanisms of the transgenerational impact of parental dietary conditions on offspring metabolic programming remain still unclear. We hypothesized, that metabolic alterations in the offspring caused by changes in parental dietary conditions are associated with inherited changes in metabolic enzyme activities. To address these questions, we reared parental flies on diets supplemented with different yeast concentrations (a main source of protein), but all offspring being placed on standard food. We found, that yeast concentration in the parental diet influences $\mathrm{MDH}$, LDH, AST, ALT activity and urea content in parents and offspring Drosophila. Our data showed that the low content of yeast in the parental diet caused the higher activity of LDH and urea content, but lower MDH activity of parental group both sexes. Increased AST and ALT activities are associated with increased yeast content in the experimental media. We have also demonstrated, that the low content of yeast in the parental diet influence higher $\mathrm{MDH}$, $\mathrm{LDH}, \mathrm{AST}$ and urea content in the progeny.

\section{Materials and Methods}

Insects, maintaining and conditions. We used Canton S (D. melanogaster Meigen) flies which were received from the Bloomington Stock Center
(Indiana University, USA). Flies were grown on the medium that consists of $4 \%$ of sucrose, $4 \%$ of dry yeast, $1.2 \%$ of agar and $0.18 \%$ nipagin as an antifungal agent. Flies were reared at $25^{\circ} \mathrm{C}$ and relative humidity of $60-70 \%$ on a $12 \mathrm{~h}$ day/night cycle [16]. Parental male and female flies were housed together for five days. Then, flies of parental generation were separated by sex and placed separately at standard densities of 200 flies per $1.5 \mathrm{~L}$ demographic cage with the attached $25 \mathrm{ml}$ plastic vial filled by the $5 \mathrm{ml}$ of experimental food. Media were composed of $4 \%$ of sucrose and dry yeast concentrations $0.25,4,10$, and $15 \% ; 1.2 \%$ of agar, $0.18 \%$ of nipagin. We have previously shown that the median lifespan of flies is $40-50$ days [6]. On the $24^{\text {th }}$ day of the experiment that referred to as the middle of their life, flies of the parental generation were divided into two cohorts. The first cohort of parental flies was combined for mating and egg-laying (Fig. 1). Thirty parental flies were frozen in liquid nitrogen for biochemical measurements.

Offspring larvae from all experimental groups were allowed to develop on the same regular food. The day after eclosion, offspring flies were transferred and held for an additional 3 days for mating to provide nutrient-dependent plasticity in females Drosophila [17]. The three-day-old offspring were frozen in liquid nitrogen for biochemical measurements.

For biochemical measurements, pre-weighted flies of both generations were homogenized in $10 \mathrm{mM}$ of ice-cold sodium phosphate buffer ( $\mathrm{pH}$ 7.4) (ratio 1:10) with further centrifugation $(16000 \mathrm{~g}$, $15 \mathrm{~min}, 4^{\circ} \mathrm{C}$ ). Received supernatants were used to measure investigated biochemical parameters [3].

Determination of enzymatic activities. Activities of malate dehydrogenase (MDH, EC 1.1.1.37), lactate dehydrogenase (LDH, EC 1.1.1.27), alanine transaminase (ALT, EC 2.6.1.2), and aspartate transaminase (AST, EC 2.6.1.1) were determined by assaying the rate of NADH oxidation, which is proportional to the reduction in absorbance at $340 \mathrm{~nm}$ over time $[3,18]$. The ALT and AST activities were determined by using the commercial diagnostic kits (PZ Cormay S.A., Poland). Activity all of the enzymes measured spectrophotometrically on Specol 211 (Jena, Germany) at $340 \mathrm{~nm}$ and calculation was made using an extinction coefficient of $6220 \mathrm{M}^{-1} \cdot \mathrm{cm}^{-1}$. The activities of MDH, LDH, ALT and AST were presented as international units (or milliunits) per milligram of soluble protein (mU/mg protein). 


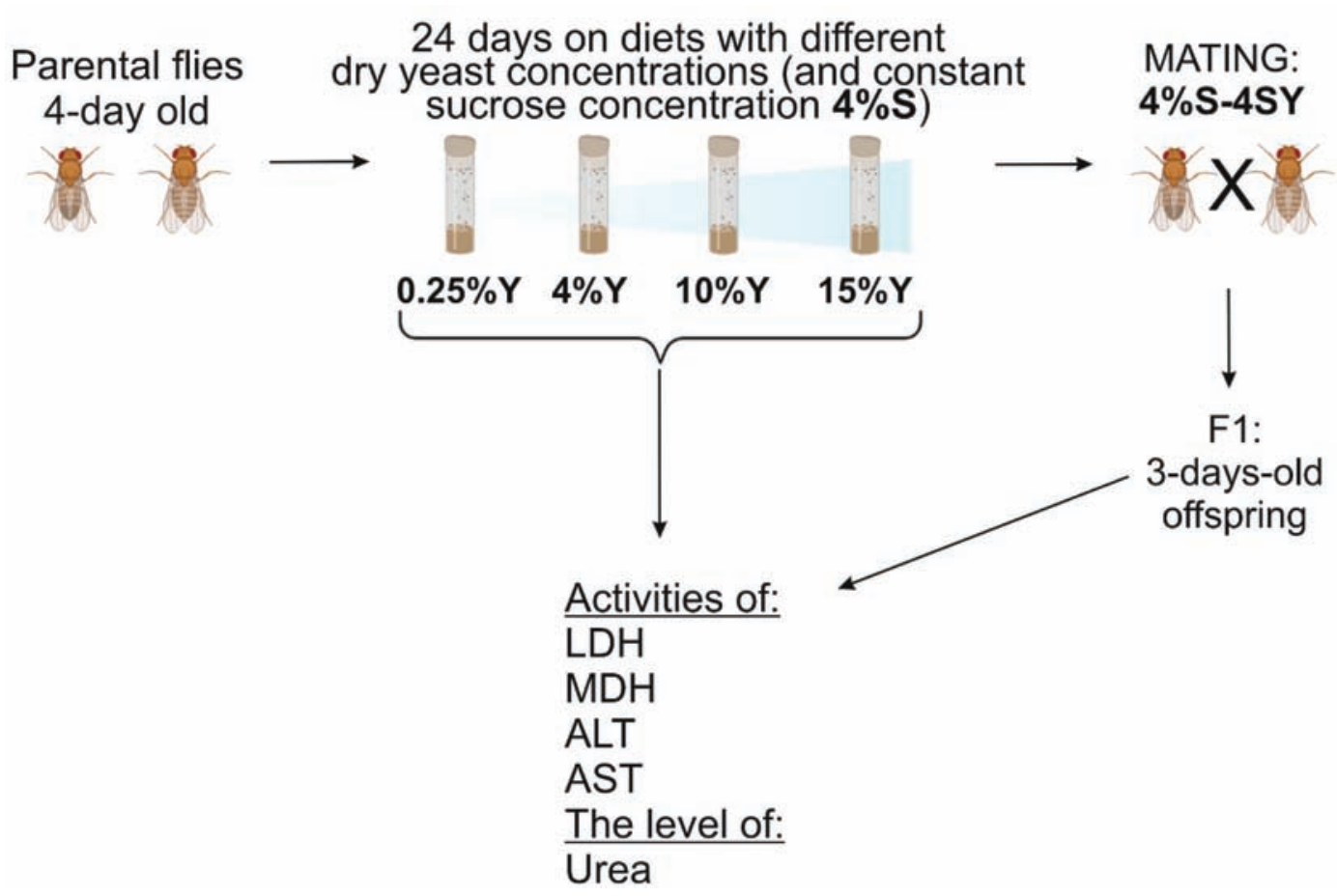

Fig. 1. Experimental design. Metabolic enzymes activity and urea content were investigated in Drosophila melanogaster of parental and offspring generations when parents were subjected to diets with $4 \%$ sucrose (S) and various dry yeast $(Y)$ concentrations $(0.25 \%, 4 \%, 10 \%$ and $15 \%)$

Total protein assay. The concentration of total protein was measured according to the Bradford method [19]. The amount of protein was determined in supernatants with the dye Coomassie Brilliant G-250 at $595 \mathrm{~nm}$ using bovine serum albumin as a standard.

Determination of urea. The method for urea determination was based on the monitoring of concentration NADH oxidized by glutamate dehydrogenase coupled to urease reaction where ammonia was formed from urea. Urea content was expressed as nanogram per milligram wet mass (ng/mgwm) $[3,18]$. Change in absorbance was recorded on Specol 211 (Jena, Germany) at $340 \mathrm{~nm}$ and calculation was made using an extinction coefficient of $6220 \mathrm{M}^{-1} \cdot \mathrm{cm}^{-1}$. Urea content was expressed as nanogram per milligram of wet mass (ng/mg wm).

Statistical analysis and graphical representation. Experimental data are presented as mean \pm SEM and $P<0.05$ is considered as significantly different. Statistical analysis was performed using "Prism” (GraphPad Software, Inc.). Tukey’s multiply comparison test has been used to compare enzyme activities and urea concentration. All graphs were generated in "Graphpad Prism7”.

\section{Results}

$\mathrm{MDH}$ and $\mathrm{LDH}$ activities. Activities of lactate dehydrogenase (LDH) and malate dehydrogenase (MDH) depended on the dietary composition in the adult Drosophila [3]. The yeast content in the diet significantly affected the activity of LDH in parental flies of both sexes. We observed $\sim 35 \%$ higher activity of LDH in parental males that consumed the medium with $0.25 \%$ of yeast as compared to all other groups (Fig. 2, $A$; $P<0.02$ ). Similarly, LDH activity was significantly increased by $\sim 36 \%$ in parental females which were reared on the medium with 0.25 and $4 \%$ of yeast as compared to $10 \%$ of yeast (Fig. 2, $B ; P<0.04)$.

The activity of LDH in the offspring was significantly influenced by yeast content in the parental diet. Higher LDH activity by $\sim 31 \%$ was detected in F1 males generated by parents that consumed media with $0.25 \%$ of yeast as compared to $10 \%$ and $15 \%$ of yeast (Fig. 2, $A ; P<0.004$ ). We also observed higher LDH activity by $24 \%$ in F1 females, when their parents consumed media with 0.25 or $4 \%$ of yeast as compared to $15 \%$ of yeast (Fig. $2, B$; $P<0.04$ ).

$\mathrm{MDH}$ activity in parental flies depended on the yeast concentration in the diet. The activity was sig- 


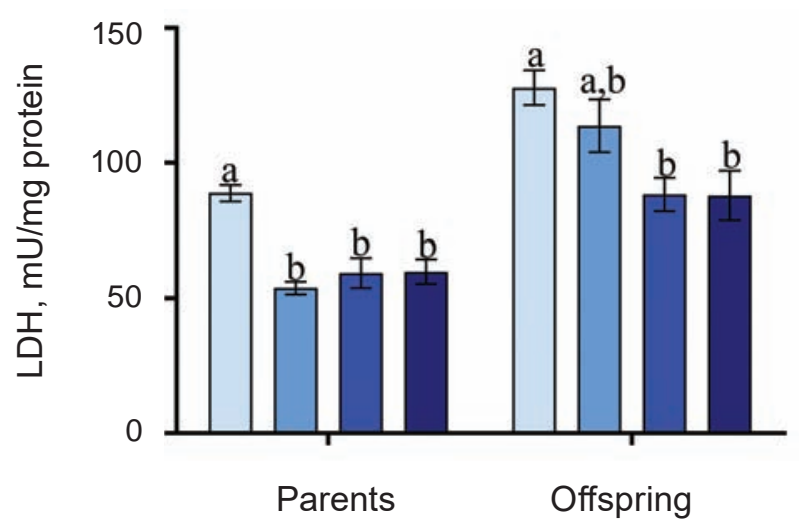

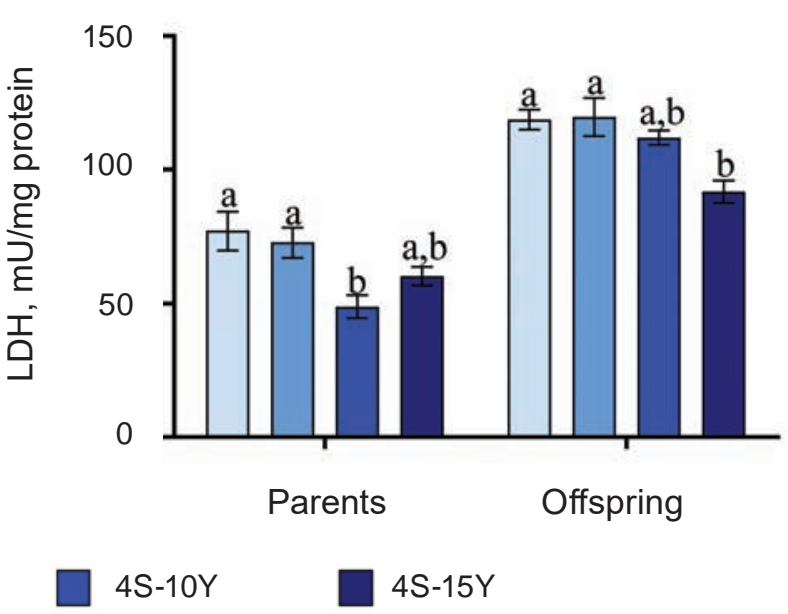

Fig. 2. LDH activity in males (A) and females (B) offspring and parents, which consumed diets with different protein concentrations. Results are shown as mean \pm SEM, $n=3-4$. Values were compared by Tukey's test. $a$-indicates the highest mean among all tested groups; $b$-indicates a significant difference from " $a$ " with $P<0.05$. Bars sharing the same letter are not significantly different according to Tukey's test

nificantly decreased by $22 \%$ in the males reared on the medium with $0.25 \%$ of yeast as compared to $4 \%$ of yeast (Fig. 3, $A ; P=0.047$ ). Consumption of the diet with $0.25 \%$ of yeast led to $\sim 43 \%$ lower $\mathrm{MDH}$ activity in females as compare to all other experimental diets (Fig. 3, B; $P<0.001$ ). Consequently, a low protein diet caused lower MDH activity.

We found the lower activity of MDH in F1 males by $31 \%$, when their parents consumed the media with 10 and $15 \%$ of yeast as compared to $0.25 \%$ (Fig. 3, A; $P<0.01$ ). However, MDH activity in F1 females was not affected by parental diet.

ALT and AST activities. The activity of alanine and aspartate aminotransferases is dependent on the presence of nitrogen and carbon sources in the diet of $D$. melanogaster $[3,20]$. The yeast content of the diet significantly affected the activity of ALT and AST in parental flies of both sexes. We observed 33\% higher ALT activity in males which consumed medium with $15 \%$ of yeast as compared to $0.25 \%$ and $4 \%$ of yeast (Fig. $4, A ; P<0.03$ ). Similarly, AST activity in males of parental generation increased in the order: $0.25 \%<4 \%<15 \%$ (Fig. 5, A; $P<0.0006$ ). We observed 23\% higher ALT activity in females fed medium with 10 or $15 \%$ of dry yeast as compared to 0.25 and $4 \%$ of yeast (Fig. $4, B ; P<0.05$ ). AST activity was significantly increased by $19 \%$ in females, which were reared on the medium with 15\% of yeast as compared to $0.25 \%$ of yeast (Fig. 5 , B; $P=0.014)$. Consequently, increased AST and ALT activities are associated with higher yeast content in the experimental media.

We found that parental dietary yeast affects AST activity in progeny flies of both sexes. The activity of AST was $26 \%$ higher in F1 males generated by parents fed medium with $0.25 \%$ of yeast as compared to 10 or $15 \%$ of yeast (Fig. 5, $A$; $P<0.008$ ). F1 females generated by parents reared on the diet with $0.25 \%$ of yeast displayed significantly higher AST activity by $19 \%$ as compared to $15 \%$ (Fig. 5, B; $P=0.049$ ). Parental dietary protein had no impact on ALT activity in the progeny of both sexes.

Urea content. Urea is a product of the catabolism of proteins and nitrogenous bases. Nutrition can directly affect the level of urea in the Drosophila body [3]. Urea concentration in females of the parental group depended on yeast concentration in the diet. Female flies, which consumed $4 \%$ of yeast had lower urea content by $30 \%$ as compared to those fed other diets (Fig. 6, $B$; $P<0.05$ ). Urea concentration in males of parental generation was not affected by protein content in the diet. However, urea content in progeny males was significantly influenced by protein content in the parental diet. F1 males generated by parents reared on the medium with $0.25 \%$ of yeast displayed a $23 \%$ higher concentration of urea as compared to the $15 \%$ of yeast (Fig. 6 , $A ; P=0.048$ ). Yeast content in parental diet had no impact on urea content in F1 females. 

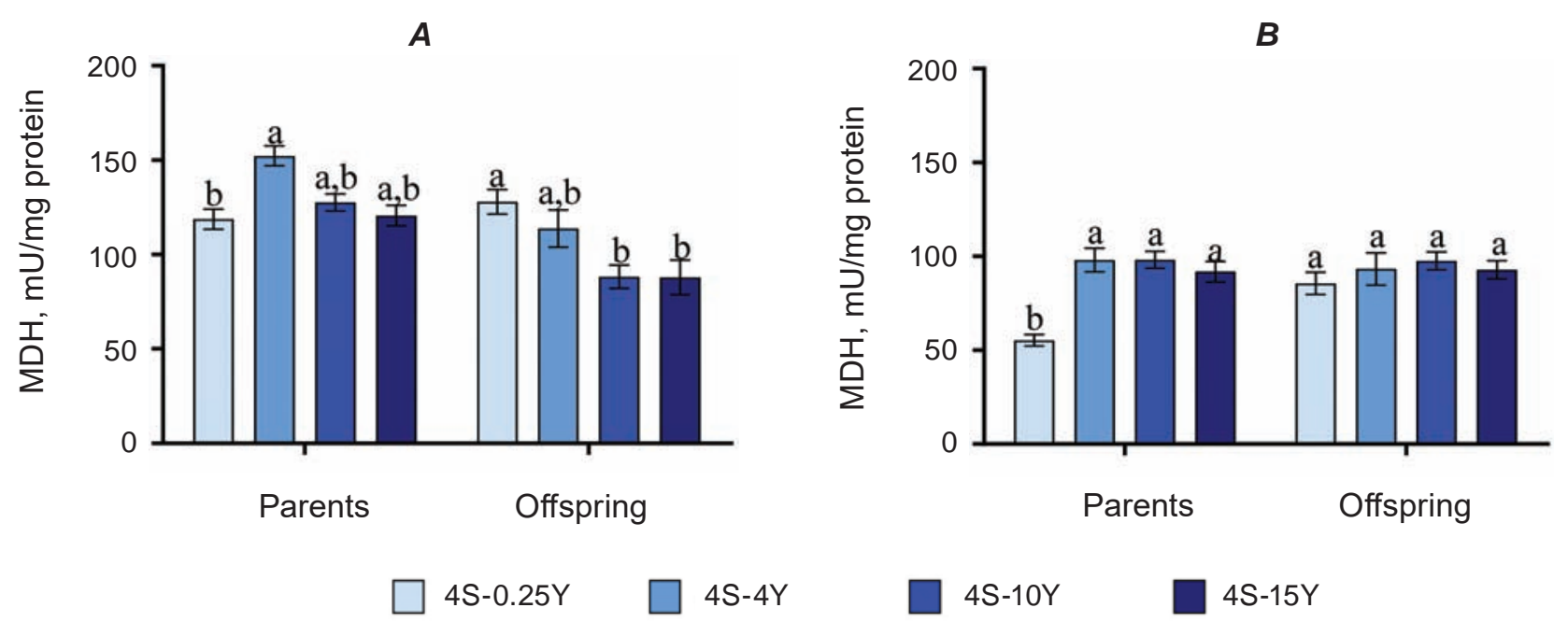

Fig. 3. MDH activity in males (A) and females (B) offspring and parents, which consumed diets with different protein concentrations. Results are presented as mean \pm SEM, $n=3-4$. Values were compared by Tukey's test. $a$-indicates the highest mean among all tested groups; $b$-indicates a significant difference from " $a$ " with $P<0.05$. Bars sharing the same letter are not significantly different according to Tukey's

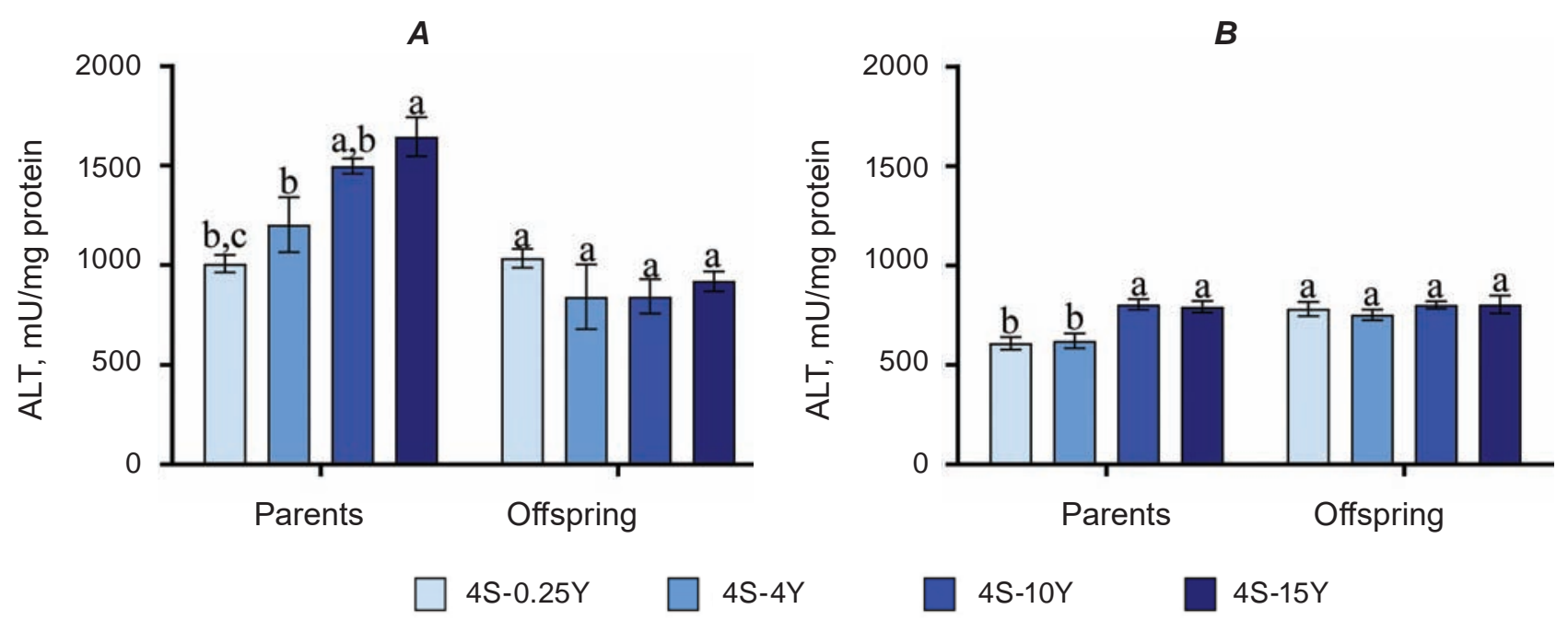

Fig. 4. ALT activity in males (A) and females (B) offspring and parents, which consumed diets with different protein concentrations. Results are presented as mean \pm SEM, $n=3-4$. Values were compared by Tukey's test. $a$-indicates the highest mean among all tested groups; $b$-indicates a significant difference from " $a$ " with $P<0.05, c$-indicates a significant difference from " $a$ " and " $b$ " with $P<0.05$. Bars sharing the same letter are not significantly different according to Tukey's test

\section{Discussion}

Numerous studies conducted on insect models have shown that diet is an important determinant of the metabolic state over multiple generations [5, $6,21,22]$. Our previous study showed, that parental protein : carbohydrates ratio has a strong and complex impact on the survival, physiological traits and metabolism of their F1 offspring that are significant indicators of Drosophila health [6]. The in- crease in $\mathrm{P}: \mathrm{C}$ ratio that is associated with decreased carbohydrate content in the parental diet results in decreased levels of body glucose and trehalose, as well as the levels of circulating hemolymph glucose and trehalose in the offspring [6]. We supposed that changes in metabolite contents in response to the parental diet that was found in the previous study may be explained by alteration in enzyme activities related to the primary metabolic pathways. We also 
$A$

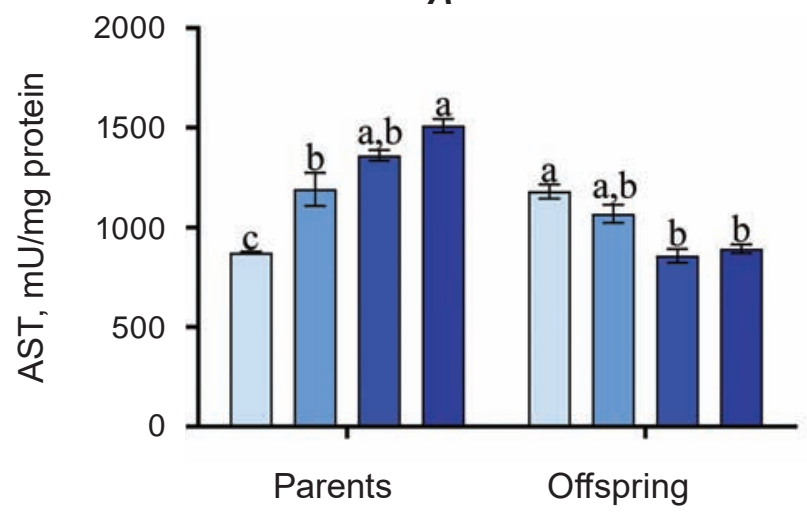

$4 S-0.25 Y$

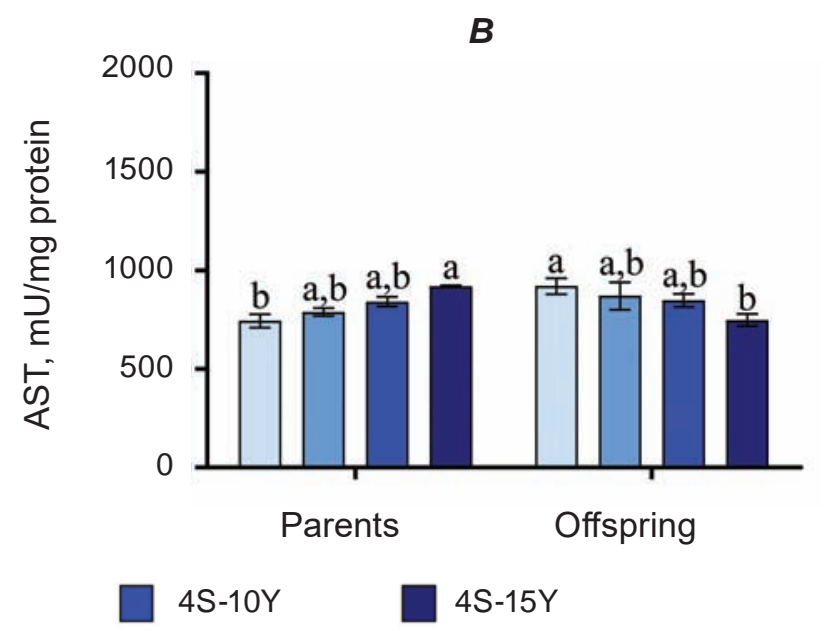

Fig. 5. AST activity in males (A) and females (B) offspring and parents, which consumed diets with different protein concentrations. Results are presented as mean \pm SEM, $n=3-4$. Values were compared by Tukey's test. $a$-indicates the highest mean among all tested groups; $b$-indicates a significant difference from " $a$ " with $P<0.05, c$ - indicates a significant difference from " $a$ " and " $b$ " with $P<0.05$. Bars sharing the same letter are not significantly different according to Tukey's test

$A$

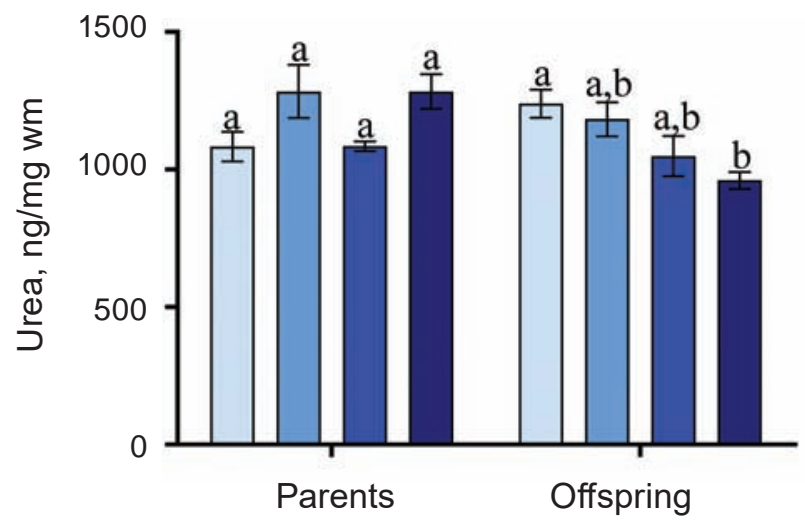

$4 S-0.25 Y$

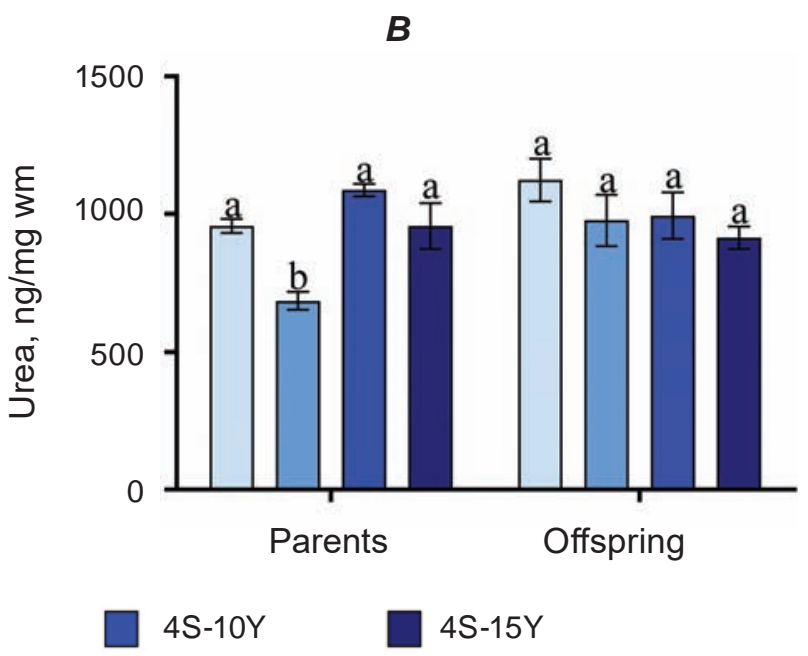

Fig. 6. Urea content in males (A) and females (B) offspring and parents, which consumed diets with different protein concentrations. Results are presented as mean \pm SEM, $n=3-4$. Values were compared by Tukey's test. $a$-indicates the highest mean among all tested groups; $b$-indicates a significant difference from " $a$ " with $P<0.05$. Bars sharing the same letter are not significantly different according to Tukey's test

suggested that consumption of the experimental media composed of sucrose (the source of glucose and fructose) and various dry yeast (the source of amino acids, carbohydrates and vitamins) content would contribute greatly to the course of the metabolism affecting various steps of carbohydrate and amino acids metabolism (Fig. 7). Moreover, we previously demonstrated the impact of variable dietary protein content in the diet of parental generation on antioxidant capacity in adult offspring Drosophila. Here we provided significant evidence of transgenerational effects in Drosophila which suggests that parental dietary protein may affect carbohydrate and amino acids metabolism of both parental and subsequent generations.

Glycolysis is one of the major pathways of central metabolism. Lactate dehydrogenase (LDH) being involved in glycolysis catalyzes the reverse conversion of pyruvate into lactate with concomitant interconversion of NADH and $\mathrm{NAD}^{+}$[23] (Fig. 7). 


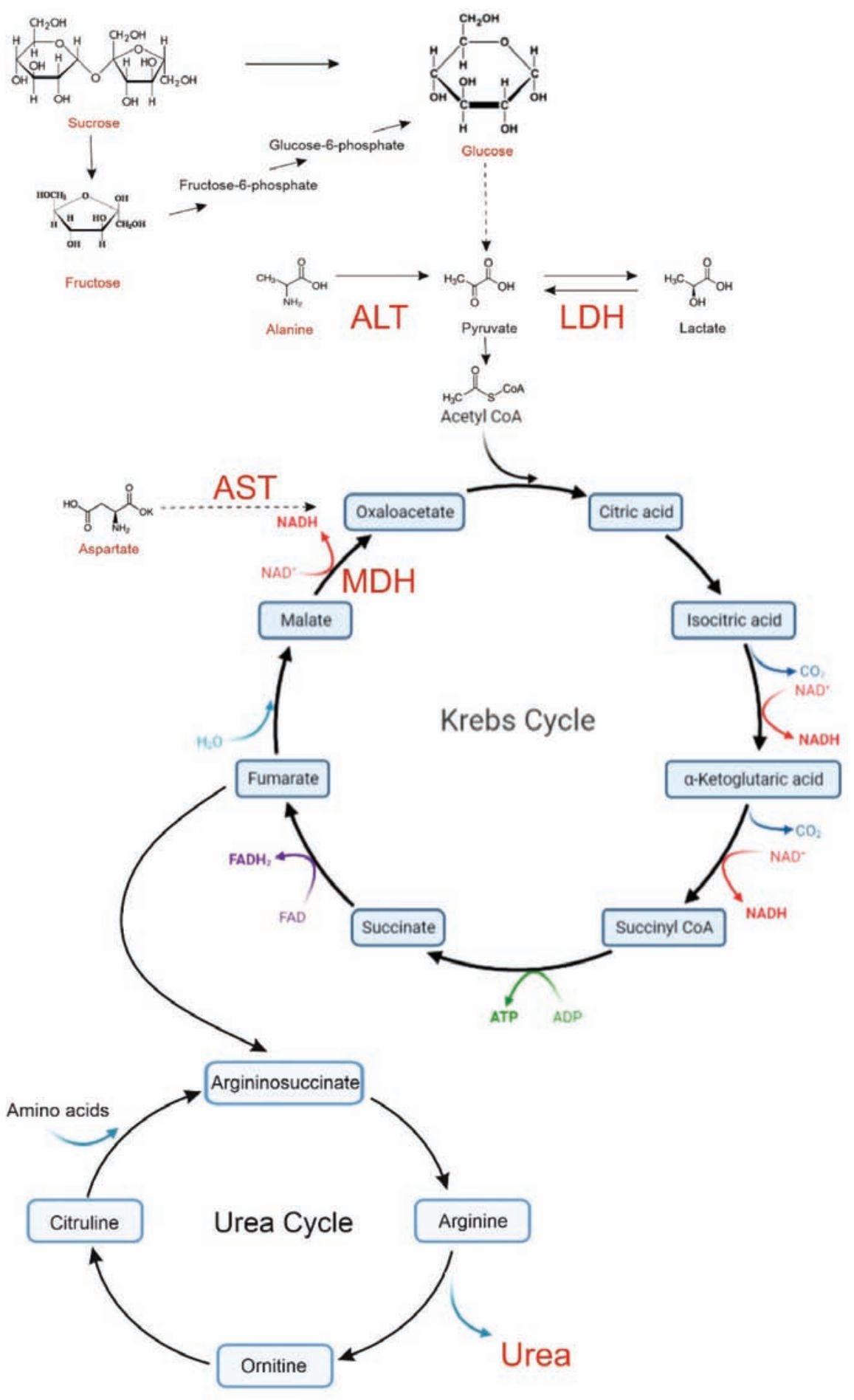

Fig. 7. Relevant central metabolic pathways. Sucrose in the experimental medium is composed of glucose and fructose, which converts into glucose. Glycolysis metabolizes glucose to pyruvate, which converts into acetyl coenzyme A (acetyl-CoA). Since alanine is a glucogenic amino acid it is readily converted by the catalytic action of alanine transaminase (ALT) to pyruvate. Under anaerobic conditions, cytosolic enzyme lactate dehydrogenase $(\mathrm{LDH})$ converts pyruvate to lactate. Aspartate transaminase (AST) catalyzes the reversible transamination of the $\alpha$-amino group from aspartate to $\alpha$-ketoglutarate forming oxaloacetate and glutamate. Malate dehydrogenase (MDH) is an enzyme in the Krebs cycle and catalyzes the reversible conversion of oxaloacetate to malate. The urea cycle is closely linked to the Krebs cycle and both are largely influenced by dietary protein content. The diagram was created with the use of BioRender software 
We detected enhanced LDH activity of both sexes in response to a low-protein parental diet. Moreover, LDH pattern in response to dietary protein was inherited in the offspring. Our previous study showed, that low sucrose content in the diet led to increased LDH activity in Drosophila [3]. LDH is not only involved in carbohydrate metabolism but is, therefore, necessary for Drosophila growth and development [24]. However, increased LDH activity observed during aging and Ldh overexpression shortens fly lifespan [23]. It was previously suggested that interventions reducing LDH activity could be considered as a potential remedy to delay aging in flies.

Malate dehydrogenase (MDH) is involved in the Krebs cycle, catalyzing the reversible conversion of malate to oxaloacetate with the participation of $\mathrm{NAD}^{+}$(Fig. 7). Cytosolic MDH activity during Drosophila larval stage has a fixed pattern but may be modulated by dietary factors. For example, a high saccharide diet increase MDH activity, while a low saccharide/high lipid diet caused MDH activity to significantly decreased [25]. We showed that low activity MDH in parental males and females related to protein restriction in the diet. Our previous study indicated that high sucrose content in the diet decreased the activity of MDH [3]. Interestingly, but yeast deprivation in the parental diet led to higher $\mathrm{MDH}$ activity in F1 males, however, had no impact on MDH activity in F1 females. Hence, MDH activity patterns can be inherited in a sex-dependent manner. These differences between males and females are found since MDH activity is regulated by both the sesquiterpenoid juvenile hormone $(\mathrm{JH})$, and the steroid hormone ecdysone [25]. Sex-specific differences in the dietary-induced inheritance of metabolism caused by a more extensive biosynthetic metabolism in females related to the need to produce eggs [26]. Furthermore, gender differences in response to dietary nutrients could be caused by differences in physiological processes, nutrient demand and/or sex differences in insulin/IGF-1 signaling (IIS) [27]. Females have higher physiological plasticity than males when consumed a protein-rich diet [29]. High levels of dietary protein stimulate IIS activity in females, however, a diet-induced increase in IIS activity was not documented [28]. It was also suggested about the involvement of IIS and TOR signaling pathways in the regulation of sexually dimorphic traits including growth, metabolism and behavior [29]. We also suggested, that predominance of the ratio of carbohydrates to protein in the parental diet caused an increase in energy metabolism in off- spring, on the contrary low activity of MDH is associated with repression of energy metabolism [30].

ALT and AST play an important role in the intermediary metabolism of glucose and amino acids [31]. Both enzymes are susceptible to dietary interventions. Increased AST activity in Drosophila is associated with low sucrose concentration in the diet [3]. High levels of dietary protein induce high AST and ALT activities in rats [32]. In the present study higher activity of ALT and AST in parental flies of both sexes was caused by high yeast concentration in the diet. However, ALT activity in the progeny flies was not affected by parental dietary protein. Interestingly, AST activity in F1 females was higher when parents were reared on the high-protein medium. Consequently, yeast content in the parental diet can contribute to amino acid metabolism in the progeny Drosophila.

Nitrogenous waste such as urea derives from nitrogen metabolism, protein degradation, and amino acid catabolism. Urea is relatively toxic at high concentrations. Urea content was not affected in parental males by the dietary yeast concentration, however, a protein-restricted diet led to a higher urea pool in F1 males. Along with the increases in urea, these data suggest that protein restriction induces a tangible change in nitrogen/amino acid metabolism in offspring. High carbohydrate concentration and a high-fat diet significantly higher enhanced the level of urea in the body of Drosophila [3, 33].

The exact genetic and mechanistic basis of dietary-induced inheritance remains unclear. However, it was suggested that evolutionarily conserved mechanisms involved in the inheritance of diet-induced physiological and metabolic changes. Previous studies discovered epigenetic markers that alter offspring life-history traits via transcriptional changes including DNA methylation and histone modifications [34]. Altered expression of genes participating in nutrient-sensing pathways such as insulinlike-growth factor (IGF), and TOR (Target of Rapamycin) is often associated with metabolic changes [35]. Rodent studies hypothesized the involvement of altered maternal mitochondria in the inheritance of metabolic traits in the F1 generation [36]. Additionally, genomic imprinting is considered as an epigenetic process that marks chromatin in a sexdependent manner [37], and these events can lead to the sex-specific effects observed in the current study.

Conclusion. Our study indicated that the parental dietary protein has a strong impact on car- 
bohydrate and amino acids metabolism in flies of both parental and offspring generations. We suggest existing adaptogenic mechanisms by which the offspring phenotype can adjust to parental environmental conditions. Dietary protein consumed by parents can contribute to varying offspring metabolism via potential epigenetic mechanisms that can modify offspring nutrient-sensing pathways. This study highlights the need for further investigations of target genes for epigenetic modifications in response to parental rearing diet. In this regard, Drosophila is an invaluable tool in uncovering the complexity of transgenerational inheritance.

Conflict of interest. Authors have completed the Unified Conflicts of Interest form at http://ukrbiochemjournal.org/wp-content/uploads/2018/12/ coi_disclosure.pdf and declare no conflict of interest.

\section{ВМІСТ ДРІЖДЖІВ У ДІЕТІ DROSOPHILA ВПЛИВАС НА МЕТАБОЛІЗМ БАТЬКІВСЬКОГО ПОКОЛІННЯ ТА ЇХ НАЩАДКІВ}

\section{О. М. Стрільбицька ${ }^{1 \bowtie}$, Н. П. Стефанишин ${ }^{1}$, У. В. Семанюк ${ }^{1}$ О. В. Лущзак ${ }^{1,2 \varpi}$}

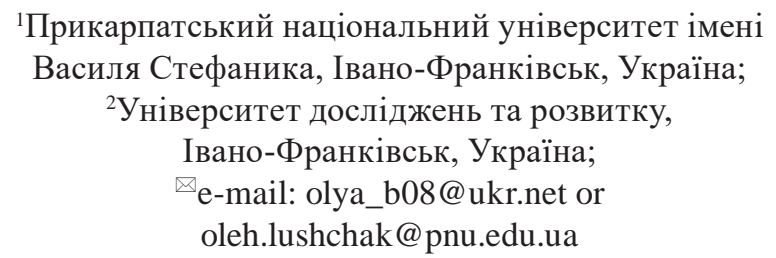

Вміст поживних речовин у харчовому раціоні батьків може епігенетично впливати на метаболізм нащадків. Результати наших досліджень виявили нові тенденції у зміні активності ензимів основних метаболічних шляхів у відповідь на вміст протеїнів у раціоні. Батьківське покоління дрозофіл утримували на середовищах із чотирма варіаціями кількості дріжджів у межах від $0,25 \%$ до $15 \%$ та сталим вмістом сахарози, але наступне покоління перебувало на середовищі однакового складу. Отже, єдиною змінною складовою в експериментах була концентрація сухих дріжджів у середовищі, на якому утримували батьківське покоління. Ми показали, що обмеження вмісту протеїнів у дієті призводило до вищої активності ЛДГ у мух батьківського покоління, а також цей ефект проявлявся у їх нащадків. Трансгенераційний ефект вмісту дріжджів у дієті батьків на активність
МДГ виявлений тільки у самців. Споживання їжі з високим вмістом дріжджів проявилось вищою активністю АЛТ у батьків, однак не впливало на активність АЛТ у їх нащадків. Навіть більше, надмірне споживання дріжджів призводило до вищої активності АСТ у батьків, однак у нащадків активність АСТ при цьому була нижчою. Виявлено вищий вміст сечовини у самців першого покоління нащадків, отриманих від батьків, які харчувались середовищем із низьким вмістом дріжджів. Наші результати продемонстрували вирішальну роль дріжджів у харчовому раціоні батьків у регуляції метаболізму, що може успадковуватися через покоління.

К лючов і слов а: харчування, дієта, протеїни, дріжджі, батьки та їх нащадки, обмін речовин, плодова мушка.

\section{References}

1. Grangeteau C, Yahou F, Everaerts C, Dupont S, Farine JP, Beney L, Ferveur JF. Yeast quality in juvenile diet affects Drosophila melanogaster adult life traits. Sci Rep. 2018; 8(1): 13070.

2. Lee KP. Dietary protein:carbohydrate balance is a critical modulator of lifespan and reproduction in Drosophila melanogaster: a test using a chemically defined diet. J Insect Physiol. 2015; 75: 12-19.

3. Strilbytska O, Strutynska T, Semaniuk U, Burdyliyk N, Lushchak O. Dietary sucrose defines lifespan and metabolism in Drosophila. Ukr Biochem J. 2020; 92(5): 97-105.

4. Lushchak OV, Gospodaryov DV, Rovenko BM, Glovyak AD, Yurkevych IS, Klyuba VP, Shcherbij MV, Lushchak VI. Balance between macronutrients affects life span and functional senescence in fruit fly Drosophila melanogaster. J Gerontol A Biol Sci Med Sci. 2012; 67(2): 118125.

5. Aldrich JC, Maggert KA. Transgenerational inheritance of diet-induced genome rearrangements in Drosophila. PLoS Genet. 2015; 11(4): e1005148.

6. Strilbytska O, Velianyk V, Burdyliuk N, Yurkevych IS, Vaiserman A, Storey KB, Pospisilik A, Lushchak O. Parental dietary protein-to-carbohydrate ratio affects offspring lifespan and metabolism in drosophila. Comp Biochem Physiol A Mol Integr Physiol. 2020; 241: 110622. 
7. Haggarty P. Epigenetic consequences of a changing human diet. Proc Nutr Soc. 2013; 72(4): 363-371.

8. Barrès R, Zierath JR. The role of diet and exercise in the transgenerational epigenetic landscape of T2DM. Nat Rev Endocrinol. 2016; 12(8): 441451.

9. Lee MJ, Yaffe MB. Protein Regulation in Signal Transduction. Cold Spring Harb Perspect Biol. 2016; 8(6): a005918.

10. Lushchak O, Strilbytska O, Piskovatska V, Storey KB, Koliada A, Vaiserman A. The role of the TOR pathway in mediating the link between nutrition and longevity. Mech Ageing Dev. 2017; 164: $127-138$.

11. Lushchak O, Strilbytska OM, Yurkevych I, Vaiserman AM, Storey KB. Implications of amino acid sensing and dietary protein to the aging process. Exp Gerontol. 2019; 115: 69-78.

12. Solon-Biet SM, McMahon AC, Ballard JWO, Ruohonen K, Wu LE, Cogger VC, Warren A, Huang X, Pichaud N, Melvin RG, Gokarn R, Khalil M, Turner N, Cooney GJ, Sinclair DA, Raubenheimer D, Le Couteur DG, Simpson SJ. The ratio of macronutrients, not caloric intake, dictates cardiometabolic health, aging, and longevity in ad libitum-fed mice. Cell Metab. 2014; 19(3): 418-430.

13. Solon-Biet SM, Mitchell SJ, Coogan SCP, Cogger VC, Gokarn R, McMahon AC, Raubenheimer D, de Cabo R, Simpson SJ, Le Couteur DG. Dietary Protein to Carbohydrate Ratio and Caloric Restriction: Comparing Metabolic Outcomes in Mice. Cell Rep. 2015; 11(10): 1529-1534.

14. Simpson SJ, Raubenheimer D. Macronutrient balance and lifespan. Aging (Albany NY). 2009; 1(10): 875-880.

15. Kapahi P, Zid BM, Harper T, Koslover D, Sapin V, Benzer S.Regulation of lifespan in Drosophila by modulation of genes in the TOR signaling pathway. Curr Biol. 2004; 14(10): 885890.

16. Rovenko BM, Perkhulyn NV, Lushchak OV, Storey JM, Storey KB, Lushchak VI. Molybdate partly mimics insulin-promoted metabolic effects in Drosophila melanogaster. Comp Biochem Physiol C Toxicol Pharmacol. 2014; 165: 76-82.

17. Bowman E, Tatar M. Reproduction regulates Drosophila nutrient intake through independent effects of egg production and sex peptide: Implications for aging. Nutr Healthy Aging. 2016; 4(1): 55-61.

18. Yurkevych IS, Gray LJ, Gospodaryov DV, Burdylyuk NI, Storey KB, Simpson SJ, Lushchak O. Development of fly tolerance to consuming a high-protein diet requires physiological, metabolic and transcriptional changes. Biogerontology. 2020; 21(5): 619-636.

19. Bradford MM. A rapid and sensitive method for the quantitation of microgram quantities of protein utilizing the principle of protein-dye binding. Anal Biochem. 1976; 72(1-2): 248-254.

20. Geer BW, Zacharias CE. Alteration of L-alanine aminotransferase, L-aspartate aminotransferase and beta-hydroxyacyl dehydrogenase activities in Drosophila melanogaster larvae by nutritional manipulation. Comp Biochem Physiol B. 1974; 47(1): 53-62.

21. Matzkin LM, Johnson S, Paight C, Markow TA. Preadult parental diet affects offspring development and metabolism in Drosophila melanogaster. PLoS One. 2013; 8(3): e59530.

22. Valtonen TM, Kangassalo K, Pölkki M, Rantala MJ. Transgenerational effects of parental larval diet on offspring development time, adult body size and pathogen resistance in Drosophila melanogaster. PLoS One. 2012; 7(2): e31611.

23. Long DM, Frame AK, Reardon PN, Cumming RC, Hendrix DA, Kretzschmar D, Giebultowicz JM. Lactate dehydrogenase expression modulates longevity and neurodegeneration in Drosophila melanogaster. Aging (Albany NY). 2020; 12(11): 10041-10058.

24. Li H, Rai M, Buddika K, Sterrett MC, Luhur A, Mahmoudzadeh NH, Julick CR, Pletcher RC, Chawla G, Gosney CJ, Burton AK, Karty JA , Montooth KL, Sokol NS, Tennessen JM. Lactate dehydrogenase and glycerol-3-phosphate dehydrogenase cooperatively regulate growth and carbohydrate metabolism during Drosophila melanogaster larval development. Development. 2019; 146(17): dev175315.

25. Farkas R, Knopp J. Genetic and hormonal control of cytosolic malate dehydrogenase activity in Drosophila melanogaster. Gen Physiol Biophys. 1998; 17(1): 37-50.

26. Perkhulyn NV, Rovenko BM, Lushchak OV, Storey JM, Storey KB, Lushchak VI. Exposure to sodium molybdate results in mild oxidative stress in Drosophila melanogaster. Redox Rep. 2017; 22(3): 137-146. 
27. Magwere T, Chapman T, Partridge L. Sex differences in the effect of dietary restriction on life span and mortality rates in female and male Drosophila melanogaster. J Gerontol A Biol Sci Med Sci. 2004; 59(1): 3-9.

28. Millington JW, Brownrigg GP, Chao C, Su Z, Basner-Collins PJ, Wat LW, Hudry B, MiguelAliaga I, RideoutEJ. Female-biased upregulation of insulin pathway activity mediates the sex difference in Drosophila body size plasticity. Elife. 2021; 10: e58341.

29. Graze RM, Tzeng RY, Howard TS, Arbeitman MN. Perturbation of IIS/TOR signaling alters the landscape of sex-differential gene expression in Drosophila. BMC Genomics. 2018; 19(1): 893.

30. Müller M, Mentel M, van Hellemond JJ, Henze K, Woehle C, Gould SB, Yu RY, van der Giezen M, Tielens AGM, Martin WF. Biochemistry and evolution of anaerobic energy metabolism in eukaryotes. Microbiol Mol Biol Rev. 2012; 76(2): 444-495.

31. Sookoian S, Pirola CJ. Alanine and aspartate aminotransferase and glutamine-cycling pathway: their roles in pathogenesis of metabolic syndrome. World J Gastroenterol. 2012; 18(29): 3775-3781.

32. Jean C, Rome S, Mathé V, Huneau JF, Aattouri N, Fromentin G, Achagiotis CL, Tomé D. Metabolic evidence for adaptation to a high protein diet in rats. J Nutr. 2001; 131(1): 91-98.

33. Heinrichsen ET, Zhang H, Robinson JE, Ngo J, Diop S, Bodmer R, Joiner WJ, Metallo CM, Haddad GG. Metabolic and transcriptional response to a high-fat diet in Drosophila melanogaster. Mol Metab. 2013; 3(1): 42-54.

34. Carone BR, Fauquier L, Habib N, Shea JM, Hart CE, Li R, Bock C, Li C, Gu H, Zamore PD, Meissner A, Weng Z, Hofmann HA, Friedman N, Rando OJ. Paternally induced transgenerational environmental reprogramming of metabolic gene expression in mammals. Cell. 2010; 143(7): 1084-1096.

35. Stegemann R, Buchner DA. Transgenerational inheritance of metabolic disease. Semin Cell Dev Biol. 2015; 43: 131-140.

36. Grindler NM, Moley KH. Maternal obesity, infertility and mitochondrial dysfunction: potential mechanisms emerging from mouse model systems. Mol Hum Reprod. 2013; 19(8): 486-494.

37. Macdonald WA. Epigenetic mechanisms of genomic imprinting: common themes in the regulation of imprinted regions in mammals, plants, and insects. Genet Res Int. 2012; 2012: 585024. 